International Journal of Environment, Agriculture and Biotechnology
Vol-6, Issue-2; Mar-Apr, 2021
J Journal Home Page Available: https://ijeab.com/
Journal DOI: $10.22161 /$ ijeab

\title{
Supply Chain of Fish Performance and Analysis Fisherman Share in Paotere Landing Fish, Makassar City
}

\author{
Nur Indah Pratiwi, Danial Sultan, Syahrul Djafar
}

Department of Coastal Management and Marine Technology, Faculty of Marine and Fisheries Science , Indonesian Muslim University, Makassar, South Sulawesi, Indonesia.

Received: 29 Jan 2021; Received in revised form: 21 Mar 2021; Accepted: 09 Apr 2021; Available online: 28 Apr 2021 (C)2021 The Author(s). Published by Infogain Publication. This is an open access article under the CC BY license (https://creativecommons.org/licenses/by/4.0/).

\begin{abstract}
Fishing port is a center for marketing of catches, where the role and facilities are very important in the economy of a port, starting from landing to marketing the catch. Several studies can be carried out to overcome this problem, one of which is the supply pattern which can be described in study of the supply chain at the Paotere Fish Landing Base which is located in the middle of Makassar City. The purpose of this study is to explain how the supply chain system, supply chain flow with the problems and chain models that exist in PPI Paotere. The author also relates using the Fiherman Share analysis. The method used in this research is purposive sampling with descriptive analysis approach. The results showed that business actors and the supply chain system at the Paotere Fish Landing Base consisted of 2 supply chain systems consisting of 1 channel, namely, Fishermen-Collectors-Retailers-Consumers, the highest occurred in flow chain 1 by 68\%, - where The percentage is greater than flow 2, namely the final 62\%, while for channel 2 it consists of fishermen-collectors-exporters (UPI)-final consumers. fisherman's share
\end{abstract}

Keywords-Supply Chain, Marketing, Fishing Port, Paotere, Fisherman Share.

\section{INTRODUCTION}

The marine and fisheries sector is one of the important sources of economic growth due to its large supply capacity and increasing demand. The high demand mainly comes from developing countries with an increasing population (Choir, 2018). About 70 percent of the fish demand for world consumption is supplied by developing countries.

South Sulawesi capture fisheries production in 2017 amounted to 362,038 tons. This shows that marine fishery commodities in South Sulawesi can be used as a superior commodity with an important economic value. Judging from the length of the coastline covering an area of $2,500 \mathrm{~km}$ with an area of $62,482.54 \mathrm{~km} 2$, part of the area is directly adjacent to 3 (three) coastal areas, namely the southern coast of the Flores Sea with marine fishery potential of 168,780 tons / year. the eastern part is Bone Bay with 144,320 tons / year, and the western part of the Makassar Strait with 307,300 tons / year (Central Statistics Agency, 2020)
A fishing port is a center for marketing of catches, where the role and facilities are very important in the economy of a port, from landing to the marketing of catches (Lubis, 2016). The function of fishing ports in marketing the catch includes the availability of facilities, services and the availability of information systems. These three indicators are very important in a fishing port. Fishery commodities fluctuate according to the amount of production and prices. Production fluctuations are caused by catches that depend on the season, while price fluctuations are caused by shifts in demand and supply of fresh fish. Several studies can be carried out to overcome this problem, one of which is the supply pattern which can be described in a study of the supply chain at the Paotere Fish Landing Base (PPI) which is located in the middle of the city of Makassar (Danial, 2018).

One of the PPIs in South Sulawesi, which is located in Makassar City, is PPI Paotere, which is a type D landing point for fish, where capture fisheries in Paotere are a parameter to improve the economy in the South Sulawesi region. 
The Paotere Fish Landing Base (PPI) is one of the Regional Technical Implementing Units (UPTD) which is directly responsible for the Makassar City Office of Marine, Fisheries, Agriculture and Livestock. PPI Paotere functions as a place for boats / fishing boats to be anchored or moored. In addition, it functions for marketing and processing of fishery products as well as a place for fostering fishing communities. PPI Paotere managers collaborate with the Fisheries Insan Cooperative in order to provide convenience and benefits for fishermen's businesses in utilizing existing facilities at PPI. This collaboration can support the income of the Makassar City fishery community and increase local revenue (PAD) (Arbi, 2016)

The function of PPI Paotere it is not only as a place to land, marine fish, but fish originating from inland fisheries (ponds) are also landed and auctioned off at PPI Paotere. The fish caught are then distributed to the final consumer in a number of ways. According toto (Indrajit, 2010) in Anatan and Ellitan (2015), supply chain is a new concept in implementing an integrated and structured logistics system, which is the process of supplying raw materials to the final buyers. The fish supply chain process needs to be distributed quickly and use cold chain.Fish has a fast-rotting nature, so poor handling and supply chain processes will reduce the quality of the fish. Apart from being a fish distributor, the supply chain system also acts as a price differentiator in each fishery chain. The supply chain system also functions to determine traceability.

Currently, PPI Paotere is the center where fishermen, traders and fish buyers meet. PPI Paotere is an inter-island market that connects fishermen from islands around Makassar including Lae-Lae Island, Kodingareng Lompo Island, Kodingareng Keke Island, Barrang Caddi Island, Barrang Lompo Island and other islands. Seeing the current strategic conditions in PPI Paotere as well as the demand for fresh fish quality must be met, it is necessary to study how fish supply in PPI Paotere is, what are the characteristics of the actors involved in fish procurement, how to manage fish from the supplier to the final distributor, diversity Fresh fishery products and fish supply chain management problems at the Paotere Fish Landing Base (PPI), from the above problems, the authors examine the performance of the fish supply chain and Fisherman Share analysis at the Paotere fish landing base (PPI) Makassar.

\section{$>\quad$ Time and Place of Research}

This research was conducted at the Paotere Fish Landing Base (PPI), which is located on the northern coast of Makassar City, at Sabutung, Pattingan Loang, Wajo Subdistrict, Makassar City in September-November 2020. Starting with preparation, data collection, data analysis and finally a discussion of the research results as outlined in the Thesis.

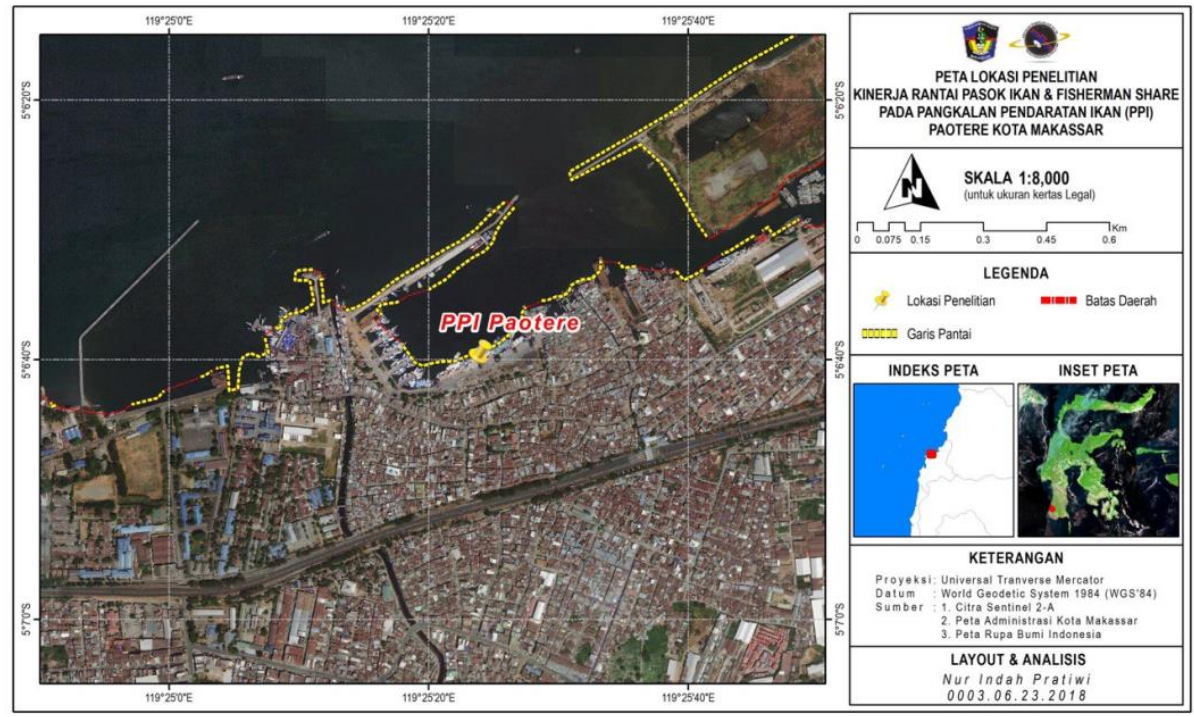

Picture 1. Research Location

\section{Sample and Population}

The population chosen is the stakeholder who knows internally and externally the condition and is able to provide answers and confirmation of the questions asked by means of interviews (depth interview). The samples in this study were 27 fishermen with ship's engine power $<15$ GT, 32 collectors, 8 big traders and 39 retailers. While the sample which is representative of the population, was taken by using purposive sampling method.

\section{$>$ Method of CollectingData}


As a complement to fulfilling the required data in this study, it is very important to use the interview method (deep interview) in data collection used to answer the problems in the study to get the correct conclusions. Therefore, researchers use data collected through observation, interviews with stakeholders, and Gathering information or documentation

\section{$>$ DataAnalysis}

The data analysis carried out in this research is qualitative analysis and quantitative analysis, based on the formulation of problem number 1 and 2 used a qualitative analysis using a descriptive analysis approach, the researcher will describe who the actors are involved and will be presented through a flowchart, agreement between actors, stocks. available, information, problems, and financial systems. The solution to problem number 3 can be used quantitative analysis with the calculation of Fisherman Share. the results obtained are in accordance with the facts.

\section{RESULTS AND DISCUSSION}

After conducting research and conducting some analysis of the data obtained in the field, we will then conclude the results and discussion, as follows:

\section{Main Actors in the PPI Paotere Supply Chain}

The fishermen in PPI Paotere consist of catch fishermen, collector fishermen and fishermen outside the region. Catch fishermen are fishermen who carry out fishing activities directly on the sea. Collectors in the supply chain process at PPI Paotere are tasked with buying fish caught directly from fishermen. The price offered by collectors is low. Exporters in the supply chain structure are responsible for distributing or distributing fish to corporate / consumer partners. Before distributing this company, sorting fish size and fish quality for export, retailers (Bakul / Pagandeng) in the supply chain process are tasked with buying small-scale catches. Bakul at PPI Paotere only buys fish from collectors, not directly from fishermen. Bakul sells fish on a port scale, and around auctions in Makassar.

The supply chain system in PPI Paotere consists of 2 chains. In channel 1, fishermen sell $100 \%$ of the fish they catch every day to collector traders, whether they are partnered or not. The relationship that is bound between fishermen, boat owners and collectors makes fishermen have to give all their catch to the collecting traders. Giving and investment is given by collecting traders to fishermen and boat owners, so that fishermen are greatly assisted in carrying out fishing operations. the collectors docked at the PPI jetty to pick up fish from fishermen who mostly come from the Pangkep Islands and Makassar City then the collectors sell fish to the retailers who come. The payment system from collectors to retailers is debt or paid in full according to the belief and subscription concept that is carried out. In this second channel chain is slightly different, fishermen who have the fish catch will distribute their catch to collectors as fishing business financiers then distributed again to the UPI (fish processing unit) to then be processed according to the contract or the target market, whether it is local and international market until it reaches the end consumer.

\section{Information Flow System, Goods, Finance}

The flow of material feeds the production of fish caught from the PPI Paotere fishing fleet. Domersal and pelagic fish that are unloaded from ships are landed without going through an auction or what is commonly called the opow system. Fishermen land the fish in the port dramaga, then collectors or ship owners accompany the calculations carried out by the weigher. In supply chain flows 1 and 2, all catch is distributed to collector traders, then the fish is distributed to retailers or stored in cold storage for sorting and storage.

Information management is related to how the actors involved manage the existing information, while the ordering process is how the retailer and exporter order fish from the supplier (fisherman). The agreement between the actors is related to how the fishermen, collectors, exporters and retailers make agreements with related parties. The source of information for each fish collector and retailer is different. Fishermen play an important role because they know the price of fish based on the type, condition and stock of fish. Fish traders at PPI Paotere order fish from suppliers by using short messages (SMS), telephone or Whatsapp (WA).

The system for determining the price of fish at PPI Paotere starts from sales made at PPI. After a purchase has been made by the trader, each trader determines the price according to their respective market conditions. Fish market retailers determine their own prices, but the price set by these traders is sometimes based on observations on prices in the market or prices set by other retailers.

\section{Fisherman Share}

Fisherman's share serves to see how much percentage of the share is received by fishermen. The value of fisherman's share is obtained by comparing the price at the fishermen level with the price at the end consumer level. 
Table I. Fisherman Share Analysis of Fish Supply Chain in PPI Paotere

\begin{tabular}{|c|c|c|c|}
\hline $\begin{array}{c}\text { Description } \\
\text { Supply Chain }\end{array}$ & $\begin{array}{c}\text { Average Initial Price } \\
(\mathbf{R p} / \mathbf{K g})\end{array}$ & $\begin{array}{c}\text { Average Final Price } \\
(\mathbf{R p} / \mathbf{K g})\end{array}$ & $\begin{array}{c}\text { Percentage } \\
(\%)\end{array}$ \\
\hline Chain I & Rp.41.667.00,- & $\operatorname{Rp} 61.026 .00,-$ & $68 \%$ \\
\hline Chain II & Rp.41.667.00,- & Rp66.625,00 & $62 \%$ \\
\hline
\end{tabular}

Data source, primary data processing 2020

Based on the data in table 1 above, the highest fisherman's share occurred in flow chain 1 at $68 \%$, with an average price from the initial producer of IDR 41,667.00 and an average final price of IDR 61.026.00 where the percentage is greater from flow 2 that is $62 \%$. Supply chain flow I is a flow that involves fishermen, collectors, retailers and consumers. Thus, this flow is a flow that has the most efficient marketing efficiency compared to other streams. This flow is included in indirect distribution, indirect distribution is a flow that uses two or more intermediaries before going to consumers (Mursid, 2016).

Meanwhile, stream 2 becomes a stream that has a smaller fisherman's share value with a value of $62 \%$, this indicates that the price received by fishermen tends to be less. This is in accordance with the opinion (Sudiyono, 2001) that commodities that are produced at a high unit cost must be sold at a high price, so that the share received by fishermen (fisherman's share) is smaller. This shows that flow 1 and 2 are the same flow which is quite beneficial for fishermen, because according to (Erzal et al. 2016), if the fisherman's share value is above $50 \%$, it can be ascertained that the marketing that occurs is efficient, while below $50 \%$ marketing can be ascertained. what happens is inefficient.

In the second chain flow, the percentage value is smaller, because there is a high margin difference between the buying price of collectors and the selling price to export. This is due to the demand for fish by exporters to collectors who choose fish of good quality and size so that the selling price is high, so the fisherman share analysis at PPI Paotere is efficient because every marketing channel from the beginning to the end already has a percentage of fisherman's share. range above $50 \%$.

\section{Supplay Chain Model}

The performance of the fish supply chain at PPI Paotere which is carried out by institutions / stakeholders that play a role in the supply chain process results in 2 supply chain flow schemes. The Supply Chain scheme at PPI Paotere can be seen from the picture below:

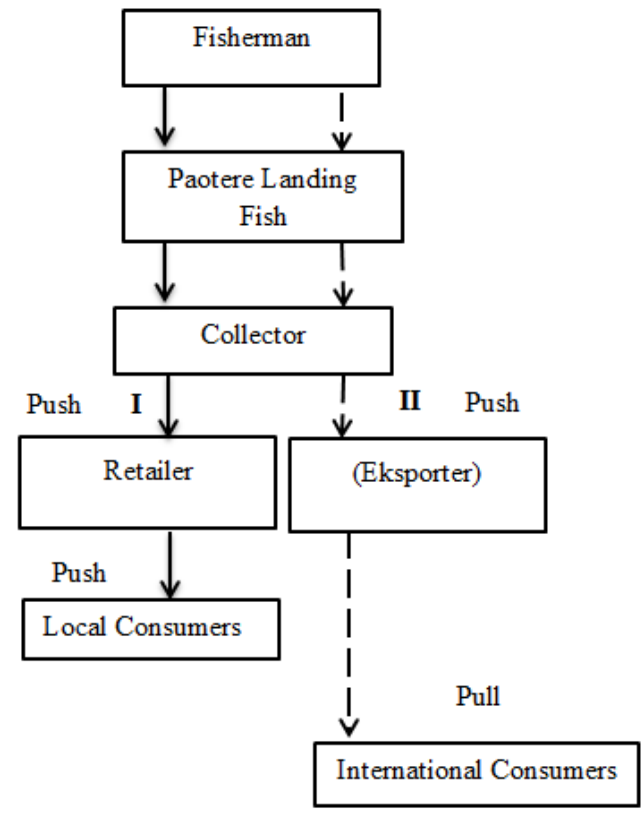

Picture 2. Scheme Of Supplay Chain In Paotere Fish Landing Station

The results of descriptive analysis, which can be seen in the supply chain flow diagram I note that most of the processes in the supply chain process are push processes. This occurs because the demand for fresh fish has to adapt to the catch of fishermen's fish which is not always the same and the berthing time is uncertain, so there is no dependence on fish demand from collectors and is also not dependent on time.

The relationship between supply chain actors I and II in business activities is a relationship that brings together suppliers, distributors, retailers, companies, retailers to the final consumer, in the flow of a supply chain to be able to produce a fish product and distribute the product in the right amount, at the right time. precise, good quality, and cost efficient to meet needs. This good relationship occurs in supply chain II where demand for fish species by UPI (fish processing units) which aims to be exported must match the right amount, right time and good quality, therefore, supply chain actors are already familiar with and trust each other. 


\section{CONCLUSION AND SUGGESTION}

Based on the results of research conducted at the Paotere Fish Landing Base (PPI), the following conclusions can be drawn:

$>$ Supply chain business actors at the Paotere Fish Landing Base (PPI) consist of fishermen, collectors, retailers, exporters, and final consumers.

$>$ The flow of information, goods, finance and problems in the fish supply chain at the Paotere Fish Landing Base (PPI) includes, distribution systems, payment systems and information related to fish availability. The problem in the supply chain system at PPI Paotere is that the loading and unloading process of fish at PPI Paotere is mixed with other activities. The mixing of activities in one dock causes fish landing activities to be disrupted.

$>$ Based on research data, the highest Fisherman's share occurred in flow chain 1 by $68 \%$, and the smallest was in flow 2 , namely $62 \%$

$>$ The supply chain scheme in PPI Paotere for Flow 1 is Fishermen-Collectors-Retailers-End Consumers. Channel 2 consists of fishermencollectors-exporters (UPI) -the final consumers

Based on the results of research carried out at PPI Paotere, several suggestions are needed, namely the need for efforts from the port, fishermen and all facility users at PPI Paotere to optimize PPI facilities, for example by managing existing facilities, Need to improve service quality, improve human resource quality, as well as the development of environmentally friendly fishing gears. It is necessary to do counseling related to high and low economical fish processing and the need to develop fish supply chain problems to identify market segmentation.

\section{REFERENCES}

[1] Arbi F. 2016. Development of Capture Fisheries at the Paotere Fish Landing Base (PPI) Makassar [Thesis]. Bogor Agricultural Institute, Bogor.

[2] Danial, Hamsiah, Syahrul, Yusuf M 2018 A model fish Marketing At Paotere fishing Ports for Increasing Fisherman Income [Jurnal]. International journal of deflopment research, Vol 08, April 2018

[3] Indrajit R.E., Djokopranoto, R. 2010. Supply Chain Management Concepts. Grasindo Jakarta

[4] Kurniawan Riski 2018 in the journal Sudiyono, Agricultural Marketing. Malang (ID): UMM Press.

[5] Lubis, E. 2016. Fishing Port [Thesis]. Bogor, Bogor Agricultural University.
[6] Mursid, M. Maghfiroh. 2016. Application of Decision Making Techniques in Supply Chain Management. IPB Press. Bogor

[7] Sudiyono. 2015 Agricultural Marketing. Muhammadiyah University of Malang. Malang: UMM Press.

[8] Soeratno D., Jan A.H. 2016. Analysis of the Supply Chain (Supply Chain) of Mujair Fish in Eris District, Minahasa Regency. Emba Journal 4 (2): 602-612

[9] Sinaga, G., Rosyid, A ,. And Wibowo, B. A. 2016 Optimization of the Level of Use of Basic and Functional Facilities at Nizam Zachman Ocean Fishing Port, Jakarta in Support of Fishing Activities. Journal Of Fisheries Resources Utilization Management And Technology 